\title{
Measuring Managerial Decision-Making: The DMQ Methodology
}

\author{
Miroslav Frankovsky ${ }^{1}$, Zuzana Birknerova ${ }^{1, *}$, Lucia Zbihlejova ${ }^{1}$ \& Ladislav Suhanyi ${ }^{1}$ \\ ${ }^{1}$ Faculty of Management, University of Prešov in Prešov, Slovakia \\ *Correspondence: Faculty of Management, University of Prešov in Prešov, Slovakia. E-mail: \\ zuzana.birknerova@unipo.sk
}

Received: November 2, 2017 Accepted: November 27, 2017 Published: November 28, 2017

doi: 10.5296/jcgr.v1i1.12198ＵRL: https://doi.org/10.5296/jcgr.v1i1.12198

\begin{abstract}
Decision-making plays an important role in management as managers' decisions have a multiplicative impact in various areas of organization. However, managerial decision-making is influenced by a number of personality and situational factors. The contribution thus presents the results of verification of a new, original methodology Decision-Making Questionnaire (DMQ), proposed on the basis of the Vroom-Yetton model of decision-making (Fotr et al. 2006). From the methodological viewpoint, DMQ is based on the dispositional, trans-situational approach to studying personality traits. The factor analysis enabled extraction of four factors explaining $47 \%$ of variance. These factors represent four decision-making styles defined by two dimensions (own information - acquired information, I make my own decisions - I make collective decisions with others).
\end{abstract}

Keywords: Management, Decision-making, Manager, Decision-Making Questionnaire (DMQ) 


\section{Managerial Decision-Making}

As decision-making takes place in a context of freedom and choice (Papula \& Papulová 2014), managers need a space which is bounded by the dimensions of authority and responsibility. Definition of this area is essential for effective managerial decision-making, the process characteristics and style of which are in this area affected by personality factors, such as the manager's situational conditions of implementation of the decision. However, the manager is a person who is ultimately responsible for the decision made and for implementation and checking the results that have been achieved (Procházková \& Remeňová 2014).

The discussion about how much the decision-making itself affects personality traits of managers or situational conditions of implementation of the decision is incorporated into a much wider debate about the dispositional and situational methodological concepts of learning. This discussion is concentrated on addressing the issue of whether it is possible to carry out prediction of behavior based on the knowledge of stable, dispositional, trans-situational characteristics which influence behavior regardless of a particular situation, or how much a particular situation or the type of situations (their perception) modifies the specified behavior (Terry 1994; Carver et al. 1989; Parkes 1986; Holahan \& Moos 1987).

\subsection{Theoretical Background}

The issue of managerial decision-making is of interdisciplinary character (Peterson 2009). Economists, philosophers, psychologists, IT experts, statisticians and other experts from various fields of knowledge engage in its meaningful and effective examination. Several authors (e.g. Weihrich \& Koontz 1988) included decision-making among continuous managerial functions (analysis, decision-making, implementation) which, together with the sequence functions (planning, organizing, controlling, human resources and management), form a complex of management functions. It is also necessary to draw attention to the fact that the decisions are affected by several personal characteristics of managers, as well as situational factors, where executive decisions are implemented (e.g. Grasseová 2013; Frankovský et al. 2015; Zibrínová et al. 2015).

In terms of the decision-making process, Grasseová (2013) emphasizes the deviation between the actual and the desired state and specifies this process in different stages which in a certain time sequence follow each other. In this context, Adair (2007) specifies the sequence of the various stages as follows: defining the objective, obtaining information, anticipating solutions, taking decisions, implementing the decisions, and evaluating the results. What is common for various approaches to identifying the stages of the decision-making process are generally accepted steps of the decision-making problem identification, design, choice of solutions and checking the results (Adair 2007).

In addition to concepts related to the decision-making process, the attention regarding this issue is also paid to identification of different styles of decision-making. Following the presented research project, it is possible to provide another example - the Vroom and Yetton's (1973) model of decision-making. This model is based essentially on the concept of two 
dimensions (Fotr et al. 2006). The extreme points of the first dimension are characterized by managers relying only on their own information or using the information from their co-workers. The extreme points of the second dimension are defined by the managers making decisions either alone or in cooperation with their colleagues. This particular model of managerial decision-making is considered by the authors of the presented research as one of the essential concepts of studying managerial decision-making. It has become the key concept of the proposed research project presented later in this paper.

As for the debates over dispositional and situational aspects of decision-making, according to Frankovský (2001), one group of authors agree that there are relatively stable forms of behavior and decision-making, which, irrespective of specific aspects of the situation, affect the decision-making process. The common, generalized trans-situational stability in human behavior in terms of decision-making is accepted. In this sense, the particular situation is usually characterized as a trigger of the decision-making process.

Another group of authors points out that the choice of conduct and the decision-making method are influenced by the situation factors (e.g. Ruiselová 1994). At the edges of this approach, one needs to consider the fact that in principle it is impossible to predict the method of decision-making. Every situation corresponds to an original and unrepeatable decision-making and the analysis can only focus on back-reflections and deduction of the reasons for this decision-making, or the reasons for the success or failure of the decisions taken.

The third opinion group represents the approach accentuating the importance of the interaction of personality, dispositional and situational factors (Frankovský 2001). Effective managerial decision-making in this context is the result of an interaction of personality traits and situational conditions of implementation of the decision-making process, accepting the aforementioned space defined by powers and responsibilities of managers.

Based on the above-mentioned theoretical and methodological ideas about the concepts of managerial decision-making it is possible to specify one typical research line in terms of defining a particular taxonomy or a typology of decision-making processes and decision-making styles.

\section{Research}

The main aim of the presented research is, on the basis of the proposal and verification of the original methodology, to contribute to the expansion of knowledge in the area of managerial decision-making. The shift in knowledge relates to identification of the decision-making attributes and definition of the taxonomy and typologization of managerial decision-making (more in Frankovský et al. 2016).

\subsection{Research Methods}

The researchers used their own methodology for assessment of the decision-making attributes (Decision-Making Questionnaire - DMQ) based on the Vroom and Yetton's model (Fotr et al. 


\section{Al Macrothink}

Journal of Corporate Governance Research

ISSN 1948-4658

2017, Vol. 1, No. 1

2006). The questionnaire consists of 20 items that enable assessment of the decision-making process from different perspectives. The given items were evaluated on a 5-point Likert scale where: $1=$ definitely no, $2=$ no, $3=$ neither no nor yes, $4=$ yes, $5=$ definitely yes.

\subsection{Research Sample}

The sample consisted of 252 respondents, including 110 male managers (44\%) and 142 female managers $(56 \%)$. The average age of the respondents was 32.9 years. The youngest respondent was 25 years, while the oldest respondent was 56 years (standard deviation: 5.77 years).

\subsection{Research Results}

Factor analysis of principal components with Varimax rotation allowed extraction of four attributes (Table 1). The first explains $17.112 \%$ of variance, the second explains $13.651 \%$ of variance, the third explains $7.991 \%$ of variance and the fourth explains $7.763 \%$ of variance. The eigenvalues of each attribute are greater than 1 and the accumulated factors explain $47 \%$ of variance, which meets the required conditions. For further explanation:

* Factor I represents a decision-making style in which the manager makes a decision alone on the basis of own information.

* Factor II represents a decision-making style in which the manager decides in cooperation with others, but makes the decision only on the basis of own information.

* Factor III represents a decision-making style in which the manager decides alone but using the information from others.

* Factor IV represents a decision-making style in which the manager decides in cooperation with others, also using and accepting the information from others.

This factor structure is also supported by the results of the Scree plot and Cronbach's alpha values (Tables 1, 2; more in Frankovský et al. 2016).

Table 1. Extracted Factor Analysis of DMQ

\section{DMQ items}

Decision-making components

Type I Type II Type III Type IV

1. When making decisions, the manager should not be influenced by $\mathbf{. 5 2 3}$ other sources of information or other persons.

2. When the manager refrains from the influence of external .671 information and influence of other people in decision-making, he/she will make an appropriate decision.

3. When making decisions, the manager should rely only on $\mathbf{. 6 9 9}$ him-/herself and on his/her own information. 
4. The decision of the manager should be individual, using only $\mathbf{. 5 6 5}$ his/her knowledge because he/she is the only bearer of responsibility.

5. Before making a decision, the manager should consult with colleagues, but the decision should be carried out using his/her own information.

6. Decision-making of the manager should be based on communication with colleagues, whereas he/she should use only his/her own information as it is sufficient.

7. Managerial decision is correct and employees accept it if the manager consults it with the others, but uses only his/her own knowledge.

8. As a manager in decision-making, I would first consult with the others, but use only my own knowledge.

9. The manager should formally consult with others, but the decision should be taken only based on his/her own knowledge.

10. The manager makes the right decisions provided that he/she ostensibly consults the others, but uses only acquired own knowledge in decision-making.

11. Decision-making of the manager is effective provided that he/she makes the decision alone but first seeks additional information from others.

12. Managerial decision-making should be independent but also based on information acquired from others.

13. The manager should rely on his/her own judgment but should obtain other necessary information.

14. An effective and correct decision is made only if the manager decides alone but listens to the information from other people.

15. The manager should decide alone but also on the basis of information gathered from other people.

16. The most appropriate decision-making by managers is to do with the acceptance of information that they managed to get from other people.

17. The manager should use joint decisions made together with other people.

18. The manager should not make decisions alone only on the basis of information.

19. Joint decision-making by managers and other people is a prerequisite for an administrative decision.

20. As an effective managerial decision I consider that which is based on mutual decision-making and acceptance of information from other people. 
Table 2. Factor Analysis of DMQ and Reliability of the Individual DMQ Attributes

\begin{tabular}{ccccc}
\hline \multirow{2}{*}{ Component } & \multicolumn{3}{c}{ Initial Eigenvalues } & \multirow{2}{*}{$\alpha$} \\
\cline { 2 - 4 } & Total & \% of Variance & Cumulative \% & \\
\hline 1 & 3.567 & 17.112 & 17.112 & .673 \\
2 & 2.325 & 13.651 & 30.763 & .701 \\
3 & 1.232 & 7.991 & 38.754 & .771 \\
4 & 1.101 & 7.763 & 46.517 & .723 \\
\hline
\end{tabular}

The correlation analysis confirmed the existence of a number of statistically significant correlations between the individual attributes (Table 3).

Table 3. Inter-Correlations of the DMQ Attributes (Spearman Correlation)

\begin{tabular}{|c|c|c|c|c|}
\hline & Type I & Type II & Type III & Type IV \\
\hline Type I & & $.381 * *$ & -.019 & .055 \\
\hline Type II & & & .068 & .053 \\
\hline Type III & & & & $.359 * *$ \\
\hline
\end{tabular}

** statistical significance at the significance level of 0.01

The attribute representing Type I is a decision-making style in which the manager decides alone and based on own information. This attribute correlates positively with Type II, which represents a decision-making style in which the manager decides together with others, but still based on his or her own information. This is a positive significant correlation. Type III, which represents a decision-making style in which the manager decides alone, but using the information from others, correlates positively with Type IV, which is connected to the decision-making of managers, whose decisions consist of joint decision-making based on the information obtained from others. This correlation is also positively significant.

\section{Conclusions}

In the conducted research, the attention was focused on the assessment of decision-making. By means of the factor analysis, authors verified their own methodology, which was designed on the basis of the Vroom and Yetton's model of decision-making (Fotr et al. 2006). The above-mentioned factor analysis enabled extraction of four attributes using the main components with Varimax rotation (Figure 1).

Statistically significant correlations were, as already mentioned, found between the decision-making styles of Type I and Type II, and also the decision-making styles of Type III and Type IV (Table 3). This means that the decision-making styles based on own information correlate significantly, regardless of whether the manager decides alone or in cooperation with others. Also the decision-making styles based on acquired information correlate significantly, again regardless of whether the manager decides independently or in 
cooperation with others.

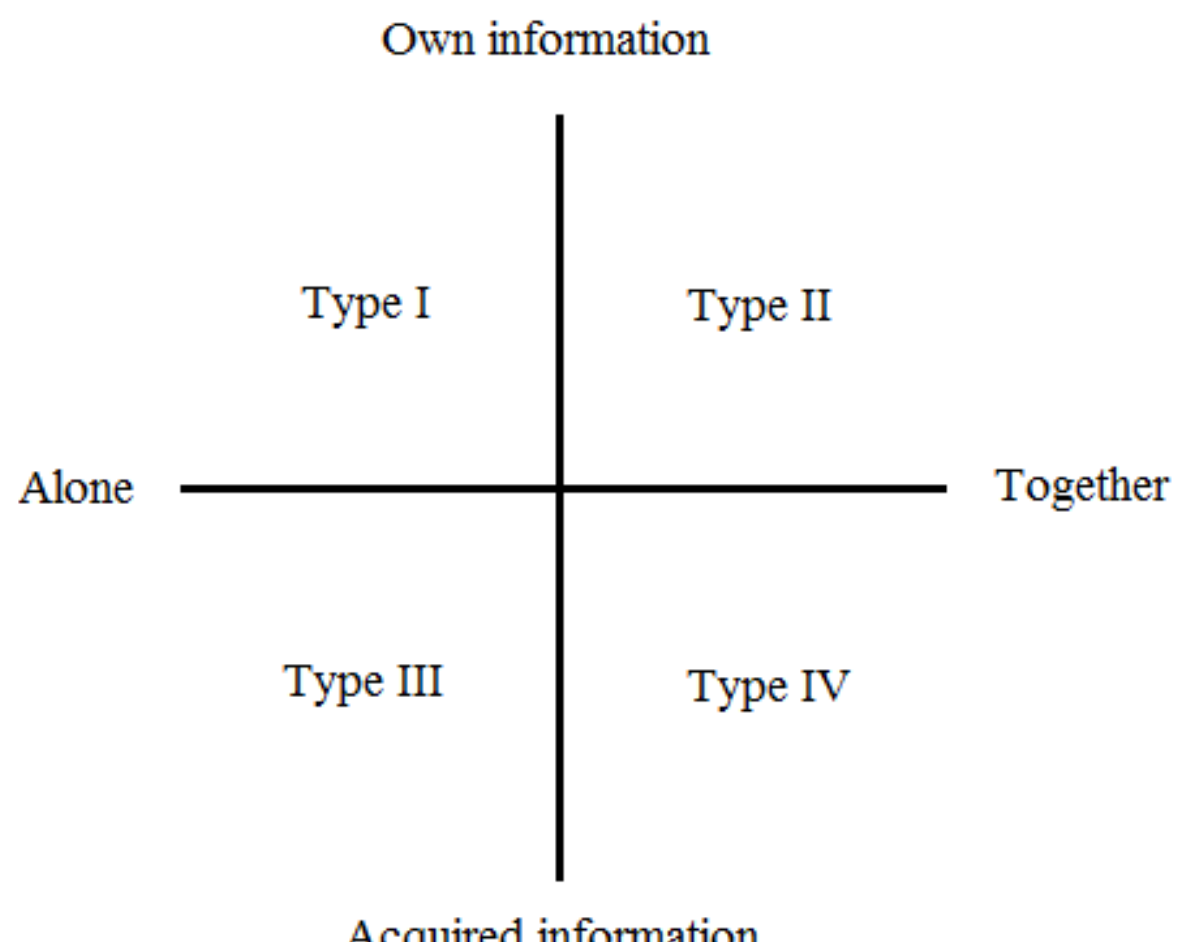

\section{Acquired information}

Figure 1. Decision-Making Styles

The detected correlations confirm the importance of information in managerial decision-making. The significance of information in the context of this decision-making acts as a separate attribute (Adair 2007; Sojka 2009), or as an important factor in the occurrence of cognitive distortions in managerial decision-making (e.g. Frankovský et al. 2015; Zibrínová et al. 2015; Samuels, Stich \& Faucher 2004).

Decision-making seems to be a process by which it is possible from various perspectives to reflect on the structural attributes of the process. The analyzed model is one possible embodiment of the given concept. It represents two natural approaches that appear in managerial decision-making: independent approach versus cooperation (autocratic vs. democratic approach), both in terms of decision-making, as well as in terms of work with information.

The presented theoretical and methodological concept of examining managerial decision-making represents an approach that is based on an analysis of the structural elements not only of this decision-making, but also the economic and social phenomena in general (Grasseová 2013; Štefko \& Krajňák 2013; Rajnoha et al. 2016, and others). 


\section{Acknowledgement}

This research was conducted with the support of the grant project VEGA 1/0909/16 (Research of determinants of decision-making in the business management and sales management, taking into account the personal and psychological aspects of trading, and analysis of the possible implications in neuromarketing).

\section{References}

Adair, J. (2007). Jak se správně rozhodovat a řešit problémy. Brno: Computer Press, a.s., p82.

Carver, C. S., Scheier, M. F., \& Weintraub, J. K. (1989). Assessing coping strategies: A theoretically based approach. Journal of Personality and Social Psychology, 56, 267-283. https://doi.org/10.1037/0022-3514.56.2.267

Fotr, J., Švecová, L., Dědina, J., Hrůzová, H., \& Richter, J. (2006). Manažérske rozhodování postupy, metody a nástroje. Praha: Ekopress, p409.

Frankovský, M. (2001). Strategies of behavior in demanding situations and the situational context. Studia Psychologica, 43(4), 339-344.

Frankovský, M., Birknerová, Z., \& Zbihlejová, L. (2015). Possibilities of identification of predictors of occurrence of cognitive distortions in managerial work. Polish Journal of Management Studies, 12(2), 69-78.

Frankovský, M., Birknerová, Z., Zbihlejová, L., \& Suhányi, L. (2016). Possibilities of identification and specification of attributes of managerial decision-making. Fifth Middle East conference on global business, economics, finance and banking proceedings. Dubai: Global business research, 15 p. ISBN 978-1-943579-27-3.

Grasseová, M. (2013). Efektivní rozhodování, analyzování, rozhodování, implementace a hodnocení. Brno: Edika, p392.

Holahan, C. J., \& Moos, R. H. (1987). Personal and contextual determinants of coping strategies. Journal of Personality and Social Psychology, 52, 946-955. https://doi.org/10.1037/0022-3514.52.5.946

Papula, J., \& Papulová, Z. (2014). Manažérske rozhodovanie: Prístupy a postupy. Bratislava: KARTPRINT, p135.

Parkes, K. R. (1986). Coping in stressful episodes: The role of individual differences, environmental factors, and situational characteristics. Journal of Personality and Social Psychology, 51, 1277-1292. https://doi.org/10.1037/0022-3514.51.6.1277

Peterson, M. (2009). An introduction to decision making. Cambridge: Cambridge University Press. https://doi.org/10.1017/CBO9780511800917

Procházková, K., \& Remeňová, K. (2014). Rozhodovanie manažérov a ich vodcovský 
potenciál. Bratislava: EKONÓM, p138.

Rajnoha, R., Štefko, R., Merková, M., \& Dobrovič, J. (2016). Business intelligence as a key information and knowledge tool for strategic business performance management. $\begin{array}{lll}\text { Economics and } & \text { management, } & 19(1),\end{array}$ https://doi.org/10.15240/tul/001/2016-1-013

Ruiselová, Z. (1994). Charakteristiky situácie a zvládanie. In Z. Ruiselová, \& E. Ficková (eds.), Poznávanie a zvládanie zátažových situácií. Bratislava: Ústav experimentálnej psychológie, 3-16.

Samuels, R., Stich, S., \& Faucher, L. (2004). Reason and Rationality. In I. Niiniluoto, M. Sintonen, \& J. Wolenski (eds.), Handbook of Epistemology. Dordrecht: Kluwer, 131-179. https://doi.org/10.1007/978-1-4020-1986-9_4

Sojka, L. (2009). Základy manažmentu. Prešov: Fakulta manažmentu Prešovskej univerzity, p104.

Štefko, R., \& Krajňák, J. (2013). An Analytical View on Fine Arts Marketing. The Jerzy Kukuczka Academy of Physical Education in Marketing, p143.

Terry, D. J. (1994). Determinants of coping: The role of stable and situational factors. Journal of Personality and Social Psychology, 66, 895-910. https://doi.org/10.1037/0022-3514.66.5.895

Vroom, V. H., \& Yetton, P. W. (1973). Leadership and Decision-Making. Pittsburgh: University of Pittsburgh Press. https://doi.org/10.2307/j.ctt6wrc8r

Weihrich, H., \& Koontz, H. (1988). Management. McGraw-Hill, p685.

Zibrínová, L., Birknerová, Z., Frankovský, M., \& Litavcová, E. (2015). Emotions in Relation to Cognitive Distortions in Thinking of the Employed and Unemployed Individuals. Economic Annals-XXI, 155(11-12), 109-113.

\section{Copyright Disclaimer}

Copyright for this article is retained by the author(s), with first publication rights granted to the journal.

This is an open-access article distributed under the terms and conditions of the Creative Commons Attribution license (http://creativecommons.org/licenses/by/3.0/). 